\title{
Den gode legen - sterk og utholdende
}

\begin{abstract}
BAKGRUNN Legene i dagens samfunn møter mange kryssende interesser fra blant andre kolleger, pasienter og arbeidsgivere. Det er forsket mye på utvikling og regulering av den medisinske profesjonen. Imidlertid er det forsket mindre på legers egne opplevelser av hva det innebærer å være en god lege.
\end{abstract}

\begin{abstract}
MATERIALE OG METODE Vi gjennomførte åtte fokusgruppeintervjuer og tre individuelle intervjuer blant overleger og leger i spesialisering som jobbet innenfor kirurgi, psykiatri og indremedisin, ved to ulike sykehus. Totalt $\mathrm{N}=48,56 \%$ kvinner. Intervjuene ble analysert med systematisk tekstkondensering.
\end{abstract}

RESULTATER «Faglig dedikasjon» vist ved «høy grad av tilstedeværelse på jobb» og «stor arbeidskapasitet» var sentrale temaer for gode leger. Stor arbeidskapasitet ble definert som viljen til å strekke seg langt, jobbe overtid og jobbe effektivt. Overlegene opplevde det å være lege mer som en «livsstil», mens leger i spesialisering i større grad så på det som en «jobb».

FORTOLKNING Norske sykehusleger ønsker å fremstå som faglig dedikerte. Dette kan de vise gjennom en sterk vilje til å jobbe hardt og effektivt med pasientarbeid og samtidig strekke seg langt for å være til stede utover regulær arbeidstid.

Det knytter seg mange krav og forventninger til hvilke oppgaver en lege skal gjøre, med hvilke midler oppgavene skal løses, og hvilken rolle legene skal innta i møte med samhandlingspartnere. Mange ulike aktører har meninger om den gode legen (1). Hva mener legene selv det innebærer å være en god lege i dag?

Det finnes mye litteratur hvor man definerer forventninger til den medisinske profesjonens idealer og forpliktelser (2-4). Oppfatningen av legen som uegennyttig hjelper, en som ønsker å gjøre alt godt for pasienten ved blant annet å tilsidesette egne behov (5), har røtter tilbake til de hippokratiske skriftene. På bakgrunn av denne oppfatningen fikk leger lenge operere nokså fritt på sitt fagområde. Fra 1970 ble det en økende skepsis mot legenes håndtering $\mathrm{av}$ den profesjonelle friheten. Samfunnsvitere som Krause (6) og Freidson (7) mente at legenes profesjonelle rolle i økende grad hadde veket for økonomiske og markedsmessige hensyn og derfor burde reguleres.

I dagens norske helsevesen er legenes rolle og funksjon regulert på forskjellige måter. I helsepersonelloven, som i 1999 erstattet legeloven, finner vi ikke lenger begrepet legeprofesjon, men samlebetegnelsen «helsepersonell». Det er lagt økende vekt på kunnskapsbaserte retningslinjer (evidence based medicine) for leger, blant annet gjennom opprettelsen av Nasjonalt kunnskapssenter for helsetjenesten (8). Pasientene har i dag andre forventninger og krav enn tidligere, med økt vekt på medbestemmelse som beskrevet i pasientrettighetsloven (9). Pasientautonomi og brukermedvirkning er nye etiske prinsipper som leger må forholde seg til (10). Kompliserte organisatoriske og sosiale strukturer påvirker sykehuslegenes rolleutforming (11), med nye arbeidsmåter $\mathrm{i}$ helsevesenet som $ø k t$ teamarbeid innad i og på tvers av profesjoner (12), samt økte krav om kostnadseffektivitet ved helseforetakene (13).

Når den tradisjonelle legerollen utfordres, kan dette håndteres på ulike måter. Profesjonen kan selv prøve å forbedre medlemmenes resultater gjennom kunnskapsbaserte retningslinjer og ved å realisere idealene om den gode lege gjennom intern disiplin og kontroll av kollegiet (14). Et eksempel på dette er Legeforeningens profesjonsetiske regler som skal bidra til at verdiene ved pasientarbeidet blir ivaretatt: «Legen skal helbrede, lindre og trøste» (15).

Leger i flere land er bekymret over at helsevesenet styres mer etter bedriftsøkonomiske prinsipper enn etter kvalitet i pasienttilbudet $(16,17)$. Flere leger mener at dette påvirker forutsetningene for å utøve et godt medisinskfaglig skjønn, og de føler seg fremmedgjort $(16,18)$. Det er interessant å se på hvordan dette påvirker nye generasjoner av leger.

Hvordan balanserer leger i sykehus disse forutsetningene og forventningene til legerollen i dag? Vi ville undersøke hvordan sykehusleger selv oppfatter hva det innebærer å være «en god lege» i dagens Norge.

\section{Materiale og metode}

Vi valgte en kvalitativ metode fordi vi var interessert i å undersøke legenes egne holdninger og perspektiver (19). Data ble samlet inn gjennom åtte fokusgruppeintervjuer og tre individuelle intervjuer i perioden 2010-2012, med til sammen 48 sykehusleger, 22 leger i spesialisering og 26 overleger, innen psykia-

\section{Tuva Kolstad Hertzberg}

t.k.hertzberg@medisin.uio.no

Forskningsinstituttet Modum Bad

Vikersund

og

Avdeling for medisinsk atferdsvitenskap

Institutt for medisinske basalfag

Det medisinske fakultet

Universitetet i Oslo

\section{Helge Skirbekk}

Lovisenberg diakonale høgskole

Oslo

\section{Reidar Tyssen}

Avdeling for medisinsk atferdsvitenskap

Institutt for medisinske basalfag

Det medisinske fakultet

Universitetet i Oslo

\section{Olaf Gjerløw Aasland}

LEFO - Legeforskningsinstituttet Oslo

\section{Karin Isaksson Rø}

LEFO - Legeforskningsinstituttet Oslo

og

Forskningsinstituttet Modum Bad Vikersund

Engelsk oversettelse på www.tidsskriftet.no

\section{HOVEDBUDSKAP}

$\AA$ A være en god lege innebærer ifølge sykehuslegene i stor grad å vise faglig dedikasjon

Faglig dedikasjon vises gjennom en sterk vilje til å jobbe hardt og effektivt med pasientarbeid og samtidig strekke seg langt for å være til stede utover regulær arbeidstid

Det å bli en god lege beskrives som en livslang prosess 
tri ( $\mathrm{n}=19,58 \%$ kvinner $)$, indremedisinske fag ( $\mathrm{n}=15,40 \%$ kvinner) og kirurgiske fag ( $\mathrm{n}=14,71 \%$ kvinner). Via kontakt med tillitsvalgte, ledere eller legemøteansvarlige informerte vi om studien. Vi rekrutterte et strategisk utvalg av overleger og leger under spesialisering fra aktuelle spesialiteter på et større og et mindre sykehus. Innenfor medisin og kirurgi intervjuet vi grupper med henholdsvis overleger og leger under utdanning. Fordi det viste seg å være svært utfordrende å samle travle sykehusleger til gruppeintervju, gjennomførte vi tre individuelle intervjuer av deltagere som ikke kunne møte i fokusgruppene. Begge intervjuene innen psykiatrien ble avholdt på et internt legemøte og besto av fremmøtte overleger og leger under spesialisering. Intervjuene (1-1,5 time) ble ledet av moderator og en eller to medhjelpere (Tuva Kolstad Hertzberg, Karin Isaksson Rø og Olaf Gjerløw Aasland), som alle var leger med ulik bakgrunn og uten tilknytning til sykehusavdelingene.

Innledningsvis inviterte moderator til samtale: «Hvordan få til en god balanse i livet som sykehuslege?» Intervjuene ble tatt opp digitalt, deretter transkribert og anonymisert $\mathrm{i}$ henhold til etiske retningslinjer. Tekstene ble analysert med systematisk tekstkondensering, som er en fire trinns analysemetode inspirert av Giorgio og utviklet og modifisert av Malterud (20). To av intervjuene ble kategorikodet av Tuva Kolstad Hertzberg og Karin Isaksson Rø, som deretter diskuterte kodingen med Helge Skirbekk. Under første koding av dataene fremsto oppfatninger rundt hva det innebærer å være en god lege som et viktig tema knyttet til balansen i livet som lege. For å undersøke dette nærmere ble dataene derfor analysert med «hva det innebærer å være en god lege» som overordnet tema.

Til slutt rekontekstualiserte vi resultatene mot datamaterialet, for å finne likheter som styrket funnene våre og ulikheter som svekket dem (21). De aktuelle underkategoriene som definerer det overordnede temaet, presenteres i resultatdelen som tekstoppsummeringer, med noen illustrerende sitater. Deltagerne i studien fikk tilbud om å lese gjennom resultatdelen for å godkjenne sitatene.

Fire av forfatterne er leger med bakgrunn fra psykiatri/arbeidsmedisin og legekårsforskning. En av forfatterne er sosiolog med forskningsfokus på kommunikasjons- og tillitsforhold i helsetjenesten.

Undersøkelsen har godkjenning fra Regional komité for medisinsk og helsefaglig forskningsetikk.

\section{Resultater}

Det kom klart frem i intervjuene at for å lære, utøve og oppdatere seg i faget, både teoretisk og håndverksmessig, kreves vilje til høy grad av tilstedeværelse på jobb og stor arbeidskapasitet. Dette har vi kalt «faglig dedikasjon». Det fremsto som den viktigste egenskapen ved en god sykehuslege og gjaldt på tvers av spesialiteter, men opplevdes til en viss grad forskjellig for leger $\mathrm{i}$ spesialisering og overleger.

\section{«Vi skal være doktorer,}

og det er ikke noe yrke, det er en livsstil»

Både leger i spesialisering og overleger beskrev faglig dedikasjon som viktig for god utredning og behandling av sykdommer hos den enkelte pasient. Uavhengig av spesialitet og karrierelengde ble faget omtalt som «morsomt» og «spennende». Det var flere som beskrev den faglig dedikerte utøvelsen av «håndverket» som «det de var utdannet til».

$\AA$ være faglig dedikert fremsto som en selvfølgelig identitetsbekreftelse, noe som ga anerkjennelse og legitimitet blant kollegene. En mannlig indremedisiner uttrykte sin beundring for kollegers faglige dedikasjon slik:

«Folk kommer inn på fritiden sin hvis det er noe de kan som den pasienten kanskje har behov for. Så kommer de og gjør det, men får ingenting for det. Det er ikke noe takk en gang som annet enn at vi på morgenmøtet så nikker vi litt sånn». (Gruppe 4)

Målet om å bli eller være faglig god fremsto som en grenseløs og livslang prosess for mange. Flere fortalte at de tilstrebet å gjøre «litt ekstra». Det på mange måter uoppnåelige idealet ved medisinfaget ble fremhevet som motiverende for flere, spesielt overlegene. Flere syntes de manglet tid $i$ arbeidsplanen for faglig fordypning og forskning, som derfor måtte gjøres på fritiden.

Slik sa en psykiater det:

«... for her (anm. i denne bransjen) blir du aldri utlært, her blir du aldri god nok, aldri flink nok og kan gå på jobben hver dag resten av livet og lære noe nytt.» (Gruppe 1)

Overleger og leger i spesialisering hadde forskjellige syn på villighet til å nedprioritere andre områder i livet enn de faglige. For overlegene fremsto det å være lege som en større del av egen identitet og livsstil. Flere av overlegene snakket om «å være doktor» mens legene i spesialisering snakket om «å jobbe som lege».

«Jeg tok ferie, men bare en uke om gangen» Flere sa at for å bli faglig god var det viktig å være mye til stede på sykehuset. En mannlig psykiater sa:

«Jeg tenker at det ofte er beinhard jobbing for å få til gode suksesskriterier. Jeg tror tilstedeværelse er viktig. Her setter en sin egen ære i at her skal det være bra.» (Gruppe 1)

Tilstedeværelse på avdelingen, ikke minst på vakt, ble beskrevet som avgjørende for å få erfaring, lære prosedyrer og få kunnskap om inneliggende pasienter. Flere overleger over 60 år som kunne slutte med vakt, ønsket å fortsette vaktarbeidet for å unngå faglig marginalisering. Leger i spesialisering som i stor grad ønsket å vise at de var faglig dedikerte, opplevde en forventning i kollegiet om tilstedeværelse utover regulær arbeidstid. Flere overleger mente at leger i spesialisering hadde betydelig mindre ansvar ved avdelingen enn de selv hadde hatt i sin tid som assistentleger. For dem var det tidlig blitt naturlig å være mye til stede på jobb, og livet for øvrig var tilpasset dette. Dette ble illustrert gjennom en humoristisk diskusjon om ferier blant tre overleger:

«Overlege 1: Jeg har aldri hatt dårlig samvittighet på ferie.

Overlege 2: Nei, for du tok jo aldri ferie før.

Overlege 1: Nei, jeg gjorde ikke det.

Overlege 3: Det gikk jo to eller tre år etter at jeg begynte her før du begynte (anm. å ta ferie).

Overlege 1: Jeg tok ferie, men bare en uke om gangen.

Overlege 2: En dag om gangen.» (Gruppe 1)

«Men alle gir $110 \%$.

Det forventes at du skal gi $110 \%$

For å kunne tilby stor grad av tilstedeværelse krevdes det stor arbeidskapasitet hos den enkelte. Arbeidskapasitet ble beskrevet som «viljen til å strekke seg litt ekstra, jobbe overtid og jobbe effektivt».

På grunn av arbeidspresset var de avhengige av at alle i gruppen fungerte bra, ikke var mye borte, jobbet hardt og var lojale. Fordi det å strekke seg langt var forventet, ble det reagert negativt når disse forventningene ikke ble innfridd, men man fikk sjelden positive reaksjoner når man innfridde forventningene:

«... det var ingen som virkelig sa noe høyt, men du hørte på kommentarene og så på blikkene at det var ikke alle som synes det var noe.» (Gruppe 3)

I ansettelsesprosesser var stor arbeidskapasitet fremhevet som et viktig kriterium blant flere overleger. En beskrev rekrutteringspolitikken slik:

«(...) jeg har i aller høyeste grad rekruttert denne staben som er her nå. Det er jo mine tidligere disipler jeg egentlig nå ledes av og det er et utplukket kobbel av toppfolk, ikke sant, som har fått det som har vært mulig å gi opp gjennom og som både vil nok og kan nok til å gjøre det bra, veldig bra. Og alle de andre de har jo valgt annerledes, ikke sant, de som ikke ville så mye (...).» (Individuelt intervju 2)

Vi fant ingen tydelige kjønnsforskjeller i materialet. 


\section{Diskusjon}

Hva det innebærer å være en god lege beskrives i denne studien som å være en faglig dedikert lege, med høy grad av tilstedeværelse på jobb, og som er villig til å jobbe effektivt og strekke seg langt for å få dette til (stor arbeidskapasitet). Det å holde et høyt faglig nivå virket som en grunnforutsetning for de fleste.

Når legene i denne studien oppga at de utvidet arbeidstiden for å øke fagkunnskapen, er det i tråd med tidligere studier som viser at sykehusleger innen flere spesialiteter oppga at minst 45 timer i uken må til for å sikre en god spesialisering (22). Selvpålagt overtid for leger har tidligere vist seg å speile avstanden mellom legenes egen vurdering av hvor mye tid som trengs for tilstrekkelig høy faglighet, og krav om kostnadseffektivitet (23).

Tilstedeværelse utover regulær arbeidstid og «viljen til å strekke seg litt ekstra» kan ligne idealene om den uegennyttige hjelperen som setter egne behov til side. Det har vært skrevet lite om hva altruisme innebærer i praksis (24). Et fravær av en slik «godt nok»-norm kan gjøre det krevende å finne balansen mellom hjem og jobb.

Vi kjenner til få andre studier hvor man har sett på legers oppfatning av hva det innebærer å skulle være en god lege, men det finnes mye forskning på medisinsk profesjonalitet. God profesjonalitet defineres ofte indirekte ved å beskrive ikke-profesjonell atferd (10). Derfor måtte vi også utforske indirekte måter å beskrive «god lege» på. I stedet for å snakke om hva det innebærer å være en god lege, snakket legene om kolleger som ikke «tilpasset seg» eller ikke «ville nok». I tidligere internasjonal forskning har man, som oss, pekt på forskjellen mellom det å se på det å være lege som en livsstil, kontra det å se på legeyrket som en jobb $(25,26)$.

Noen mener at den yngre generasjonen har byttet ut idealet om altruisme med egne interesser når de legger mer vekt på privatliv og familie $(26,27)$. Strukturen med oppdelt vaktdøgn og kortere arbeidstid kan ha ført til at yngre leger føler seg mindre personlig ansvarlige for pasientene (28) og at de dermed er mindre forpliktet $\mathrm{i}$ jobben som lege.

Utviklingen med stadig nye oppgavedelinger og subspesialiseringer kan gå på bekostning av kontinuitet i behandlingen. Teknologiske nyvinninger og håndtering av ny biomedisinsk kunnskap går ofte på bekostning av de mer humanistiske sidene av medisinen (29). På den annen side kan forskjellen i synet på legerollen mellom overleger og leger i spesialisering også representere en kohorteffekt, som vil si at dagens yngre leger vil sosialiseres inn i legerollen som «en livsstil» senere i karrieren.

Forventningen om å jobbe intenst og effektivt samsvarer med tidligere forskning som viser at det å jobbe hardt er en gjennomgående norm innen legeprofesjonen (30). Viljen til å strekke seg fremsto som grunnleggende blant legene, og som et uttrykk for dedikasjon, noe som ga legitimitet i kollegiet. I legeyrket er erfaring viktig, og det å oppnå medisinsk kompetanse handler om livslang læring. Utfordringen som fremkommer her, er om det $\mathrm{i}$ det hele tatt er mulig å være en «god nok lege».

Knyttet til det overordnede temaet om hva det innebærer å være en god lege, fant vi tydeligere forskjeller mellom overleger og leger under spesialisering enn mellom kjønn. Det er tidligere vist få forskjeller mellom kvinnelige og mannlige leger når det gjelder tilfredshet med jobben (31). Når det gjelder de hverdagslige konsekvensene av slike jobbidealer, er det imidlertid vist at kvinner og menn takler balansen mellom jobb og hjem på forskjellig måte. Kvinner reduserte antall arbeidstimer i større grad enn menn, til tross for en like stor familiebelastning målt ved antall barn (32). Manglende reduksjon av arbeidstid blant menn viste en sammenheng med emosjonell utmattelse (utbrenthet) senere i karrieren (33).

Ut fra det foreliggende datamaterialet har vi også analysert hvilke utfordringer sykehusleger opplever ved å etterleve idealene om den gode lege. Resultatene presenteres $\mathrm{i}$ en separat artikkel.

Styrken med en kvalitativ studie er at den genererer opplevelsesbasert kunnskap mer enn kvantitative rangeringer. Dette begrenser generaliserbarheten. Den eksterne validiteten av funnene i studien er likevel at materialet inkluderer leger fra et stort sentralt og et mindre lokalt sykehus, leger fra ulike fagområder og både leger i spesialisering og overleger (34).

Rekrutteringen kan ha ført til et utvalg av leger med spesiell interesse for temaet. Vi kan også ha selektert leger med større mulighet for å jobbe lange arbeidsdager, fordi intervjuene ble lagt til slutten av arbeidsdagen. Det at vi hadde tre individuelle intervjuer og åtte gruppeintervjuer kan på grunn av ulik dynamikk i de to intervjuformene ha påvirket resultatene. Deltagerne i de individuelle intervjuene ville fătt mindre taletid $\mathrm{i}$ en gruppe, og deres utsagn ville i større grad blitt påvirket av hva andre sa og motsatt. Det kan ha ført til at disse deltagerne har fått større plass i vår studie enn de enkelte deltagerne $\mathrm{i}$ fokusgruppene.

Det at moderatorene i intervjuene var leger kan på den ene siden ha fremmet forståelse og gjenkjennelse av det som beskrives, men innebærer på den andre siden en risiko for at egne antagelser kan påvirke forståelsen. «Innenfra»-perspektivet kan ha ført til at enkelte faktorer, som man antar at alle leger kjenner til, er blitt tatt for gitt og ikke blitt eksplisitt uttrykt. Vi har under analysen sett etter variasjoner rundt hovedtemaene for å styrke den interne validiteten av funnene. Funnene er også presentert og diskutert i ulike fora og forelagt deltagerne.

\section{Konklusjon}

Våre funn tyder på at legene mener at det å være en god lege henger tett sammen med en faglig dedikasjon som øker viljen til å strekke seg både i forhold til tilstedeværelse på jobb og effektivitet i pasientarbeidet, uavhengig av omstendighetene. Det blir viktig å se på hvilke konsekvenser det har for legene å skulle leve opp til disse forventningene om å være en god lege.

Vi takker leger som har deltatt i intervjuer, og som har hjulpet oss med informasjonsmøter og tilrettelegging i forkant.

\section{Tuva Kolstad Hertzberg (f. 1973)}

er lege i spesialisering i psykiatri og stipendiat. Forfatter har fylt ut ICMJE-skjemaet og oppgir ingen interessekonflikter.

\section{Helge Skirbekk (f. 1971)}

er medisinsk sosiolog med doktorgrad om pasienters tillit til leger. Han er førsteamanuensis og redaktør av antologien Tillit i Norge. Forfatter har fylt ut ICMJE-skjemaet og oppgir ingen interessekonflikter.

\section{Reidar Tyssen (f. 1955)}

er spesialist i psykiatri, dr.med., professor i medisinske atferdsfag og avdelingsleder. Forfatter har fylt ut ICMJE-skjemaet og oppgir ingen interessekonflikter.

\section{Olaf Gjerløw Aasland (f. 1944)}

er lege og seniorforsker. Forfatter har fylt ut ICMJE-skjemaet og oppgir ingen interessekonflikter.

\section{Karin Isaksson Rø (f. 1962)}

er spesialist i arbeidsmedisin, ph.d., instituttleder og overlege og har en mastergrad i helseadministrasjon og ledelse (MHA).

Forfatter har fylt ut ICMJE-skjemaet og oppgir ingen interessekonflikter.

\footnotetext{
Litteratur

1. Rothman D, Mclntosh S. Strangers at the bedside A history of how law and bioethics transformed medical decision making. Hist Philos Life Sci 1994 16. 155

2. Hafferty F. Viewpoint: the elephant in medical professionalism's kitchen. Acad Med 2006; 81: 906-14.

3. Swick HM. Toward a normative definition of medical professionalism. Acad Med 2000; 75: 612-6.

4. Freidson E. Profession of medicine: a study of the sociology of applied knowledge. Chicago, IL: University of Chicago Press, 1970 
5. Løgstrup K. Den etiske fordring. Oslo: JW Cappelens Forlag, 2000

6. Krause EA. Death of the guilds: professions, states, and the advance of capitalism, 1930 to the present. New Haven, CT: Yale University Press, 1999.

7. Freidson E. Professionalism, the third logic: on the practice of knowledge. Chicago, IL: University of Chicago press, 2001

8. Nasjonalt kunnskapssenter for helsetjenesten. http://kunnskapssenteret.no/kunnskapsbaserthelsetjeneste (3.5.2016).

9. LOV-1999-07-02-63. Lov om pasient- og brukerrettigheter (pasient- og brukerrettighetsloven). https://lovdata.no/dokument/NL/lov/ 1999-07-02-63 (8.7.2016).

10. DeJong SM. Chapter One - What is professionalism? I: De Jong SM, red. Blogs and tweets, texting and fiending social media and online professionalism in health care. San Diego, CA: Academic Press, 2014: 1-11.

11. Mesel T. Sosiologisk ramme. Legers profesjonsetikk - Refleksjon og mestring i en sykehuskultur. Kristiansand: Høyskoleforlaget, 2009: 309

12. Borgstrom E, Cohn S, Barclay S. Medical professionalism: conflicting values for tomorrow's doctors. J Gen Intern Med 2010; 25: 1330-6.

13. Wallace JE, Lemaire JB, Ghali WA. Physician wellness: a missing quality indicator. Lancet 2009; 374 : $1714-21$.

14. Aasland OG. The physician role in transition: is Hippocrates sick? Soc Sci Med 2001; 52: 171-3.

15. Etiske regler for leger Norge. http://legeforeningen. no/om-legeforeningen/organisasjonen/rad-ogutvalg/organisasjonspolitiske-utvalg/etikk/etiskeregler-for-leger/ (3.5.2016)
16. Helsetjenesteaksjonen 2015. http://helsetjenesteaksjonen.no/ (3.5.2016)

17. Makdessi L, Halmin M. Läkarupprop för en bättre sjukvård. Lakartidningen 2013; 110: CD31.

18. McKinlay JB, Marceau L. New wine in an old bottle: does alienation provide an explanation of the origins of physician discontent? Int J Health Serv 2011; 41: 301-35.

19. Oakley A. Qualitative research and scientific inquiry. Aust N Z J Public Health 2004; 28: 106-8.

20. Malterud K. Systematic text condensation: a strategy for qualitative analysis. Scand J Public Health 2012; 40: 795-805.

21. Tjora A. Kvalitative forskningsmetoder i praksis Oslo: Gyldendal Akademisk, 2012.

22. Rosta J, Aasland OG. Weekly working hours for Norwegian hospital doctors since 1994 with special attention to postgraduate training, work-home balance and the European working time directive: a panel study. BMJ Open 2014; 4: e005704.

23. Falkum E, Gjerberg E, Hofoss D et al. Tidspress blant norske leger. Tidsskr Nor Lægeforen 1997; 117: $954-9$

24. Swick HM, Bryan CS, Longo LD. Beyond the physician charter: reflections on medical professionalism. Perspect Biol Med 2006; 49: 263-75.

25. Bernat JL. Restoring medical professionalism. Neurology 2012; 79: 820-7.

26. Smith LG. Medical professionalism and the generation gap. Am J Med 2005; 118: 439-42.

27. Bickel J, Brown AJ. Generation X: implications for faculty recruitment and development in academic health centers. Acad Med 2005; 80: 205-10.

28. Tsou A, Creutzfeldt CJ, Gordon JM. The good doctor: professionalism in the 21st century. I: Bernat
$J$, Beresford R, red. Ethical and legal issues in neurology handbook of clinical neurology. 118. Amsterdam: Elsevier B.V, 2013: 119

29. Doukas DJ. Returning to professionalism: the re-emergence of medicine's art. Am J Bioeth 2004; 4: 18-9.

30. Hoff TJ, Pohl H, Bartfield J. Creating a learning environment to produce competent residents: the roles of culture and context. Acad Med 2004; 79: 532-9.

31. Scheurer D, McKean S, Miller J et al. U.S. physician satisfaction: a systematic review. J Hosp Med 2009; 4: 560-8

32. Røvik JO, Tyssen R, Hem E et al. Job stress in young physicians with an emphasis on the workhome interface: a nine-year, nationwide and longitudinal study of its course and predictors. Ind Health 2007; 45: 662-71.

33. Hertzberg TK, Isaksson Rø K, Vaglum PJ et al. Work-home interface stress: an important predictor of emotional exhaustion 15 years into a medical career. Ind Health 2016; 54: 139-48.

34. Malterud K. Metodeutfordringer. I: Malterud K. Fokusgrupper som forskningsmetode for medisin og helsefag. Oslo: Universitetsforlaget, 2012.

Mottatt 20.1. 2016, første revisjon innsendt 8.5. 2016, godkjent 8.7. 2016. Redaktør: Tor Rosness. 